\title{
Prey-size dependency of grazing by free-living marine flagellates*
}

\author{
B. C. Monger, M. R. Landry \\ Department of Oceanography, University of Hawai'i at Manoa, 1000 Pope Road, Honolulu, Hawaii 96822, USA
}

\begin{abstract}
Currently, there are 3 distinct and conflicting predictions of the dependency on prey size of the clearance rates [(volume cleared of prey) flag. ${ }^{-1}$ time $^{-1}$ ) of flagellates that feed by the mechanism of direct-interception. Clearance rates for this group of organisms have been predicted to be proportional roughly to either the first, second or third powers of prey radius indicating either weakly, moderately or strongly size-selective grazing behaviors, respectively. These predicted relationships were tested experimentally for cultured and natural flagellate populations fed mixtures of large and small fluorescently labelled prey (either heat-killed bacteria or latex microspheres). Evidence from 7 experiments indicated that flagellate feeding is only weakly size-selective; that is, clearance rate varies, roughly, in direct proportion to prey radius. These results provide preliminary support of a prey capture model that is based entirely on the interaction of hydrodynamic forces and surface forces arising between freeliving marine flagellates and picoplankton-size prey. The extent to which small size provides a refuge from grazing mortality among the picoplankton, and the potential for a significant population of dormant bacteria, is probably less than previously believed; consequently the role of the most minute bacteria in pelagic food webs may require reexamination.
\end{abstract}

\section{INTRODUCTION}

An organism's metabolic requirements, its ability to exploit resources, and its susceptibility to predation are influenced to varying degrees by its size. Consequently, size-dependencies are important aspects contributing to the structure and dynamics of pelagic marine systems. Empirically derived relationships between respiration and growth and organism size are the foundation of a general size theory of pelagic community structure (e.g. Platt \& Denman 1977, Sheldon et al. 1977). Size is a particularly important parameter at the base of the food web where morphological and functional distinctions among species are vague. The current conceptualization of the microbial food web is based upon a simple size-hierarchy of consumers (Azam et al. 1983, Fenchel 1988). Size-efficiency arguments and direct observations indicate that bacterivorous nanoflagellates are the principal consumers of, and the control point for, heterotrophic and phototrophic picoplankton populations in the open oceans (Fenchel

\footnotetext{
- Contribution 2617 from the School of Ocean and Earth Sciences and Technology, University of Hawai'i at Manoa, 1000 Pope Road, Honolulu, Hawaii 96822, USA
}

1982b, 1986a, 1988, Linley et al. 1983, Campbell \& Carpenter 1986, Iturriaga \& Mitchell 1986, Rassoulzadegan et al. 1988) and the prey, in turn, for larger ciliated protists.

Many flagellates lack elaborate feeding structures (though choanoflagellates are a notable exception); they capture prey by chance contact with their cell surface as they swim randomly through the fluid media (Fenchel 1984, 1986b). In principle, the relatively simple mechanism of 'direct-interception' does not require active prey recognition or selection behaviors by flagellates and thus, lends itself to investigating aspects of microbial food-web dynamics that may be inherently size-dependent. One such aspect is the extent to which very small size provides a refuge from predation. Maaløe \& Kjeldgaard (1966) have demonstrated that for a given strain of heterotrophic bacteria, smaller size is correlated with lower specific growth rate. It is generally believed that the smallest oceanic bacteria are starving or dormant and consequently turning over at a slower rate than are larger forms (Stevenson 1978, Wright 1984). Although size-dependent feeding by flagellates has been strongly linked to the control of bacterial community size structure (Amerman et al. 1984, Andersson et al. 1986), there is much uncertainty 
in the nature of this coupling, therefore its implications for relative growth rates and cell dormancy remain unresolved.

Presently, there exist 3 distinct theoretical or empirical relationships between prey size and clearance rates [(effective volume swept clear of prey) flag. ${ }^{-1}$ time $^{-1}$ ] of direct-interception feeding flagellates. Fenchel (1982a, 1984) suggested that if a Stokes' flow regime around a spherical grazer was assumed, and if prey followed exactly the streamlines produced by this flow, then the Geometric model of Spielman (1977) could be applied as a first approximation of prey capture by directinterception. From the analysis of this model, Fenchel predicted that clearance rate should be proportional to the square of the prey radius but cautioned that the presence of van der Waals forces and hydrodynamic boundary effects, which the Geometric model neglects, could alter this prediction and may in fact explain the discrepancies between the clearance rates predicted by the model and measured rates. Alternatively, Gonzalez et al. (1990, Fig. 3) have presented results of grazing experiments in which flagellate clearance rates appear to be linearly related to prey volume, which we infer as evidence for the possible existence of a cubic relationship between clearance rate and prey radius. The experiments of Gonzalez et al. were designed to examine the effects of prey shape on grazing and to demonstrate the existence of a size-dependent grazing component but were not intended to critically determine the exact form of the size-dependency. Consequently, no attempt was made by the authors to justify, statistically, their choice of a linear regression model relating clearance rate and prey volume over other possible regression models, and no attempt was made to advocate one size-relationship over another. Therefore, the linear dependency of clearance rate on prey volume, as conveyed indirectly by the regression model in their Fig. 3, represents an untested model of sizedependent grazing in which clearance rate is proportional to the cube of prey radius. More recently,
Monger \& Landry (1990) considered the balance of hydrodynamic and surface forces at size scales relevant to flagellates and concluded that the dependency of flagellate clearance rate on prey radius should be variable and substantially lower than the 2 previously mentioned models. Over an appropriate range of flagellate and bacteria prey sizes, the 'Force-Balance' model of Monger \& Landry (1990) predicts clearance rates roughly proportional to the 0.7 to 1.0 power of prey radius. In the present paper, we test these 3 distinct size-relationships against observed differences in the clearance rate of flagellates fed mixtures of prey differing in size and reconcile the apparent discrepancies.

\section{MATERIALS AND METHODS}

The basic design of our experiments was to feed a mixture of fluorescently labelled bacteria (FLB) or carboxylated fluorescent microspheres (FMS) (Polysciences Inc., Warrington, PA, USA) of 2 different sizes to cultured or natural populations of flagellates. These are referred to as 'FLB' and 'FMS' experiments, respectively. Grazing rates on the 2 prey were determined by following the number of labelled cells of each size ingested by the flagellates in time-course experiments. The sizes and initial concentrations of fluorescent prey for all experiments are presented in Table 1.

FLB. Cultures of the bacteria Alcaligenes cupidus and Vibrio damsela were grown at $20^{\circ} \mathrm{C}$ in nutrientenriched media $(5.0 \mathrm{~g}$ peptone and $0.1 \mathrm{~g}$ yeast extract per liter of $0.2 \mu \mathrm{m}$-filtered seawater). The cultures were harvested by centrifugation during exponential growth, then washed and resuspended in sterile minimal-salts medium for $2 \mathrm{~d}$ to starve them to a smaller mean cell size. FLB were prepared from the cell suspensions according to the protocol of Sherr et al. (1987) except that bacteria were heat-killed for $3 \mathrm{~h}$ instead of $2 \mathrm{~h}$, and in the case of $A$. cupidus, filtered through a

Table 1 Initial conditions for size-selection with flagellates feeding on fluorescently labelled bacteria (FLB) or fluorescent microspheres (FMS)

\begin{tabular}{|c|c|c|c|c|c|c|c|}
\hline \multirow[t]{2}{*}{ Experiment } & \multirow[t]{2}{*}{ Grazer } & \multirow{2}{*}{$\begin{array}{l}\text { Depth } \\
(\mathrm{m})\end{array}$} & \multirow{2}{*}{$\begin{array}{l}\text { Temp } \\
\left({ }^{\circ} \mathrm{C}\right)\end{array}$} & \multicolumn{2}{|c|}{ Large prey } & \multicolumn{2}{|c|}{ Small prey } \\
\hline & & & & $\begin{array}{l}\text { Radıus } \\
(\mu \mathrm{m})\end{array}$ & $\begin{array}{l}\text { Initial conc. } \\
\text { (prey } \mathrm{ml}^{-1} \text { ) }\end{array}$ & $\begin{array}{l}\text { Radius } \\
\{(\mu \mathrm{m}\}\end{array}$ & $\begin{array}{l}\text { Initial conc. } \\
\text { (prey } \mathrm{ml}^{-1} \text { ) }\end{array}$ \\
\hline FMS-1 & Paraphysomonas vestita & na & 15 & 0.55 & $1.1 \times 10^{5}$ & 0.25 & $1.3 \times 10^{5}$ \\
\hline FMS-2 & EP-1 & na & 15 & 0.55 & $4.2 \times 10^{5}$ & 0.25 & $5.4 \times 10^{5}$ \\
\hline FMS-3 & $\mathrm{NZP}^{\alpha} \operatorname{Stn} \mathrm{PAPA}$ & 40 & 13 & 0.55 & $2.3 \times 10^{4}$ & 0.25 & $9.3 \times 10^{4}$ \\
\hline FMS-4a & NZP $(2-4 \mu \mathrm{m}$ dia.) Stn PAPA & 60 & 13 & 0.55 & $2.5 \times 10^{4}$ & 0.25 & $9.2 \times 10^{4}$ \\
\hline FMS-4b & NZP (4-8 um dia.) Stn PAPA & 60 & 13 & 0.55 & $2.5 \times 10^{4}$ & 0.25 & $9.2 \times 10^{4}$ \\
\hline FLB-1 & VZP Stn PAPA & 40 & 1.3 & 0.51 & $4.0 \times 10^{4}$ & 0.34 & $4.1 \times 10^{4}$ \\
\hline FLB-2 & NZP Stn PAPA & 30 & 13 & 0.51 & $3.4 \times 10^{4}$ & 0.34 & $4.7 \times 10^{4}$ \\
\hline
\end{tabular}


1.0 $\mathrm{m}$ Nuclepore filter, rather than sonicated, to remove clumps. FLB were sized with an Elzone/Celloscope model $80 X Y$ particle counter (Elmhurst, IL, USA) equipped with a $15 \mu \mathrm{m}$ diameter orifice tube. Size analysis was based on measurements of at least 25000 cells. $V$. damsela had identical mean and modal equivalent spherical radii (ESR) of $0.51 \mu \mathrm{m} ; 90 \%$ of the population was between 0.40 and $0.64 \mu \mathrm{m}$ ESR. A. cupidus had mean and modal ESRs of 0.34 and $0.36 \mu \mathrm{m}$ respectively; $90 \%$ of the population was between 0.25 and $0.42 \mu \mathrm{m}$ ESR. FLB were prepared in advance of experiments at sea and were stored at $-40^{\circ} \mathrm{C}$ until needed (not more than $1 \mathrm{mo}$ ).

Flagellates. Cultures of a $10 \mu \mathrm{m}$ diameter monad, Paraphysomonas vestita, and a $3 \mu \mathrm{m}$ diameter naked flagellate (FP-1) were obtained from L. Haas (Virginia Institute of Marine Science). Both organisms were maintained at $15^{\circ} \mathrm{C}$ in seawater supplement with barley grains and transferred approximately every 2 wk. Two days before size-selection experiments, the cultures were transferred to sterile $50 \mathrm{ml}$ polystyrene centrifuge tubes without added barley. The flagellates grazed the background bacterial population to ca $5 \times 10^{6}$ cells $\mathrm{ml}^{-1}$ before the experiments were started.

Natural flagellate assemblages were studied between 30 August and 3 September 1987 at Station PAPA $\left(50^{\circ} \mathrm{N}, 145^{\circ} \mathrm{W}\right)$, Gulf of Alaska, as part of the research conducted in the SUPER (Subarctic Pacific Ecosystem Research) Program. Seawater samples, collected from depth (Table 1) in Teflon-coated Go-Flo bottles (General Oceanics, Miami, FL, USA) attached to a Kevlar line, were gently transferred to 11 Teflon bottles and placed in shipboard incubators maintained at surface temperatures (ca $13^{\circ} \mathrm{C}$ ). The samples were allowed to stabilize for 4 to $6 \mathrm{~h}$ after transfer before grazing experiments were started. Ambient bacterial concentrations were ca $5 \times 10^{5}$ cells $\mathrm{ml}^{-1}$.

Sample analysis. The time course of uptake of fluorescently labelled prey by flagellates was determined from subsamples taken periodically from experiments of 4 to $7 \mathrm{~h}$ duration. For each time point, replicate $1.0 \mathrm{ml}$ samples for experiments with cultured flagellates or $5.0 \mathrm{ml}$ samples for experiments with natural flagellate populations were prepared for microscopical analysis by fixing with a $10 \%$ solution of glutaraldehyde $\left(5\right.$ to $\left.20^{\circ} \mathrm{C}\right)$ to a final concentration of $2 \% \mathrm{v} / \mathrm{v}$, staining with DAPI (Sigma Chemical Co., St. Louis, MO, USA), and filtering onto $0.2 \mu \mathrm{m}$ black Nuclepore filters (Pleasanton, CA, USA) under low vacuum $(<80 \mathrm{~mm} \mathrm{Hg}$ ). We assume that any food vacuole egestion artifact that may have been introduced by our fixation method (Sieracki et al. 1987, Sherr et al. 1989) is independent of the size of prey contained within the vacuole. Under this assumption, while fixation artifacts may lower the estimates of the 'absolute' clearance rate, the 'relative' clearance rates on large and small prey will be unaffected. In Experiments FMS-3 and FMS-4, samples were also lightly stained with Proflavin (Sigma Chemical Co.) to allow better visualization of small flagellates. Flagellates and ingested fluorescent prey were counted with a Zeiss epifluorescence microscopoe at $1250 \times$ magnification using standard blue (Zeiss \#487709) and UV (Zeiss \#487702) filter sets. Flagellates were sized at $1250 \times$ magnification using an ocular micrometer with $0.5 \mathrm{um}$ gradations. In Experiments FMS-4 clearance rates were estimated separately for flagellates in the size ranges of 2 to $4 \mu \mathrm{m}$ diameter (FMS- $4 \mathrm{a}$ ) and 4 to $8 \mu \mathrm{m}$ diameter (FMS-4b). The number of large and small prey ingested at each time point was generally determined from analysis of 140 flagellates. Because large and small prey were not added in exactly equal concentrations (Table 1), the number of fluorescent prey ingested were converted to cumulative volume cleared (nl flag. ${ }^{-1}$ ) by dividing prey ingested by the appropriate prey concentration before plotting against time as per Gonzalez et al. (1990).

Statistical analysis. Clearance rates of flagellates on large and small prey $\left(\mathrm{Cl}_{1 \mathrm{lg}}, \mathrm{Cl}_{\mathrm{s}_{\mathrm{sm}}}\right)$ were estimated from the slopes of the linear regions of the cumulative clearance curves (Figs, 1 to 3 ). For each least-squares analysis, the slope, the standard error of the slope, and the regression coefficient were estimated using SYSTAT statistical software (SYSTAT Inc., Evanston, IL, USA). The resulting estimates of $\mathrm{Clr}_{l_{\mathrm{g}}}$ and $\mathrm{Clr}_{\mathrm{sm}}$ were then used to test the 3 predicted relationships between clearance rate and prey radius $\left(R_{p}\right)$. Since each size relationship can be written in the form $\mathrm{Clr} \propto \mathrm{R}_{\mathrm{p}}^{\beta}$, the predicted clearance rate ratio (PCRR) for large and small prey can be expressed as

$$
\mathrm{PCRR}=\frac{\mathrm{Clr}_{\mathrm{lg}}}{\mathrm{Clr}_{\mathrm{sm}}}=\left(\frac{\mathrm{R}_{\mathrm{lg}}}{\mathrm{R}_{\mathrm{sm}}}\right)^{\beta}
$$

where $\beta=0.9,2.0$ and 3.0 , respectively for the ForceBalance (FB) model, the Geometric model (GEO), and the regression model presented in Gonzalez et al. (1990, Fig. 3), hereafter referred to as the CUBIC model. It should be noted that Gonzalez et al. observed a linear relationship between clearance rate and prey volume that had a non-zero intercept, which they cautioned may or may not be real based upon the observations of other researchers. Eq. (1) ignores the possibility of such an intercept. Additionally, the predictions of size-dependent grazing from the FB model are derived numerically and vary both with the size of grazers and the size of prey. In the present analysis, FB predictions were determined from exact numerical solutions of the model using measured flagellate and prey sizes, and assumed flagellate swimming speed of $200 \mathrm{um} \mathrm{s}^{-1}$, and a non-retarded Hamaker constant of 
$3.7 \times 10^{-21}$ Joules (Monger \& Landry 1990). In the region of these parameters, clearance rates of flagellates are roughly proportional to $\mathrm{R}_{\mathrm{p}}^{0.9}$.

To test statistically our results against the 3 model predictions, Eq. (1) is rearranged to yield $\mathrm{Clr}_{\mathrm{Ig}}=$ PCRR $\cdot$ Clr $_{\mathrm{sm}}$ as per Kendall \& Stuart (1961, p. 125-126). Assuming the cumulative clearance measurements are normally distributed about each time point, the estimated slopes $\left(\mathrm{Cl}_{\mathrm{lg}}\right.$ and $\left.\mathrm{Clr}_{\mathrm{sm}}\right)$ will be normally distributed (Sokal \& Rohlf 1981, p. 474). Thus, each PCRR can be examined using a simple 2-sample test of the Student's $t$-statistic,

$$
t_{2(n-2)}=\frac{\mathrm{Clr}_{\mathrm{lg}}-\mathrm{PCRR} \cdot \mathrm{Cl}_{\mathrm{sm}}}{\sqrt{\mathrm{S}_{\mathrm{lg}}{ }^{2}+\mathrm{PCRR}{ }^{2} \cdot \mathrm{S}_{\mathrm{sm}}{ }^{2}}},
$$

where $n=$ number of data points used in the linear regression; $2(n-2)=$ degrees of freedom; and $S_{\lg }$ and $\mathrm{S}_{\mathrm{sm}}=$ standard errors of $\mathrm{Clr}_{\mathrm{lgg}}$ and $\mathrm{Clr}_{\mathrm{sm}}$ estimates, respectively. Exact 2-sided p-values were determined for each model prediction using logarithmic interpolation of Student's t-table (Rohlf \& Sokal 1981).

\section{RESULTS}

The results of the 7 size-selection experiments are depicted in Figs. 1 to 3. The upper sections of the graphs for each experiment show the time course of cumulative (density-corrected) volume clearance for flagellates feeding on paired large and small prey. Under the experimental conditions, cumulative clearance increased linearly for periods of 1 to $5 \mathrm{~h}$ with an average of about $4 \mathrm{~h}$. Based on arguments of Sherr et al. (1988), this implies that the average time required to digest and or egest the content of a single food vacuole is ca $4 \mathrm{~h}$. This egestion-digestion time is about 4 times longer than that found by Sherr et al. (1988) for a mixture of 3 flagellates feeding on FLB at similar temperatures, but less than or equal to the egestion time inferred by us from the data of Pace \& Bailiff (1987, Fig. 3) for a chrysomonad feeding on fluorescent microspheres at $20^{\circ} \mathrm{C}$. It is debatable whether the linear increase in cumulative clearance over such long periods resulted from long digestion times or from conditioning artifacts (e.g. surface conditioning of prey models or flagellates becoming more accustomed to these prey models). Therefore, the clearance rates determined from the slope of these lines, and the following discussion, must be viewed with some caution. With the exception of Experiment FMS-2, calculated clearance rates (range 0.07 to $5.7 \mathrm{nl} \mathrm{flag.}{ }^{-1} \mathrm{~h}^{-1}$, mean $1.5 \mathrm{nl}$ flag. ${ }^{-1} \mathrm{~h}^{-1}$; Table 2 ) are comparable to previously published rate estimates for similar-sized flagellates feeding on fluorescently labelled prey (e.g. Sherr et al. 1983, 1987, McManus \& Fuhrman 1986, 1988, Sieracki et al. 1987. Nygaard et al. 1988, Gonzalez et al. 1990). The bottom-sections of Figs. 1 to 3 show the ratios of cumulative volume cleared of large and small prey computed for each time point during the experiments. Since flagellates grazing negligibly affected the densities of fluorescently labelled prey in these experiments, the mean ratios, depicted by horizontal lines, are indicative of the relative rates of ingestion of large and small prey by the flagellates. The ratios generally fall between 1.0 and 2.0 and show little consistent pattern of variations with time since the start of feeding.

For the size ratio of the large and small microspheres available in the FMS experiments $\left(R_{l g}=0.55 \mu \mathrm{m} ; R_{s m}=\right.$ $0.25 \mu \mathrm{m}_{i} \mathrm{R}_{\mathrm{lg}} / \mathrm{R}_{\mathrm{sm}}=2.2$ ), Eq. (1) predicts that clearance rates on the large microspheres should exceed those on the small microspheres by factors of about 2.0 for the
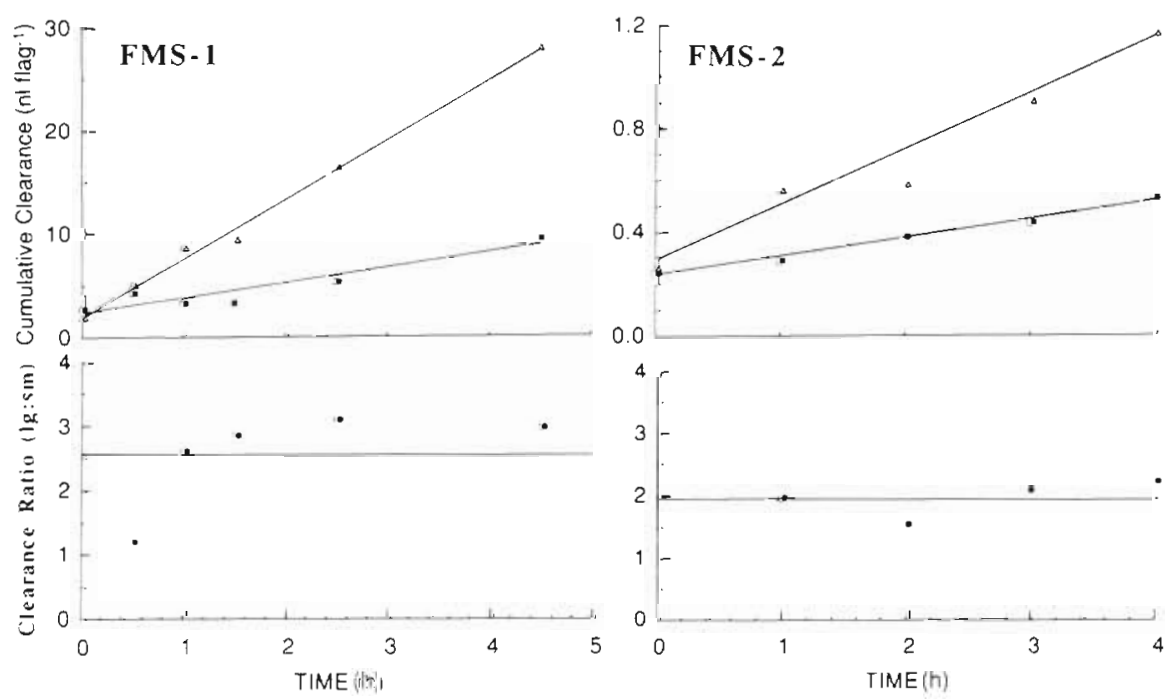

Fig. 1 Time course of cumulative clearance on large $(i)$ and small (-) fluorescent microspheres (upper); and ratios of cumulative volume cleared of large and small microspheres (lower) for Paraphysomonas vestita (FMS-1) and a naked zooflagellate (FMS-2). Predicted clearance ratios are roughly 2,5 and 11 for FB, GEO and CUBIC models respectively (see Table 2) 

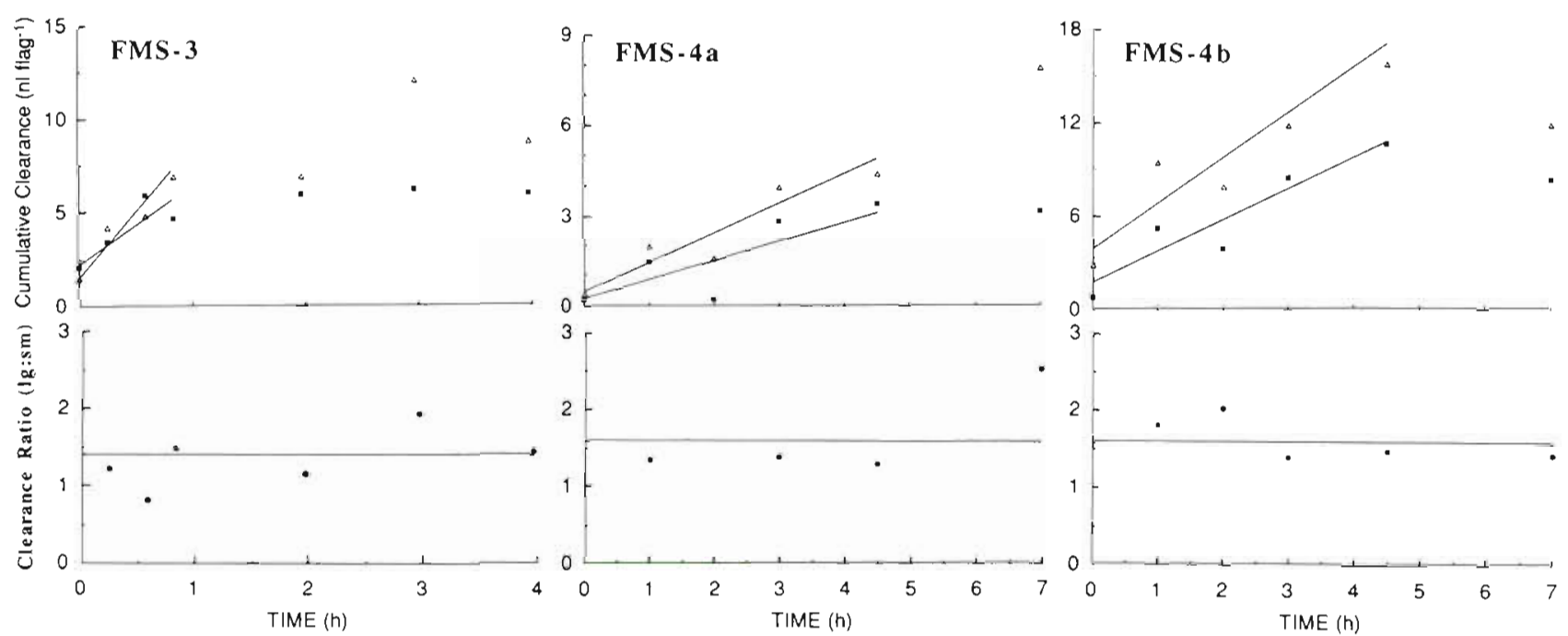

Fig. 2. Time course of cumulative clearance on large (.) and small ( $\mathbf{0}$ ) fluorescent microspheres (upper); and ratios of cumulative volume cleared of large and small microspheres (lower) for natural grazer populations obtained from the subarctic Pacific. FMS-3: whole population; FMS-4a: 2.0-4.0 $\mathrm{m}$ diameter zooflagellates; FMS-4b: 4.0-8.0 $\mu \mathrm{m}$ diameter zooflagellates. Predicted clearance ratios are roughly 2,5 and 11 for FB, GEO and CUBIC models respectively (see Table 2)

Fig. 3. Time course of cumulative clearance on large $(\Delta)$ and small (-) fluorescently labelled bacteria (upper); and ratios of cumulative volume cleared of large and small bacteria (lower) for natural grazer populations obtained from the subarctic Pacific. Predicted clearance ratios are roughly 1,2 and 3 for FB, GEO and CUBIC models respectively (see Table 2)
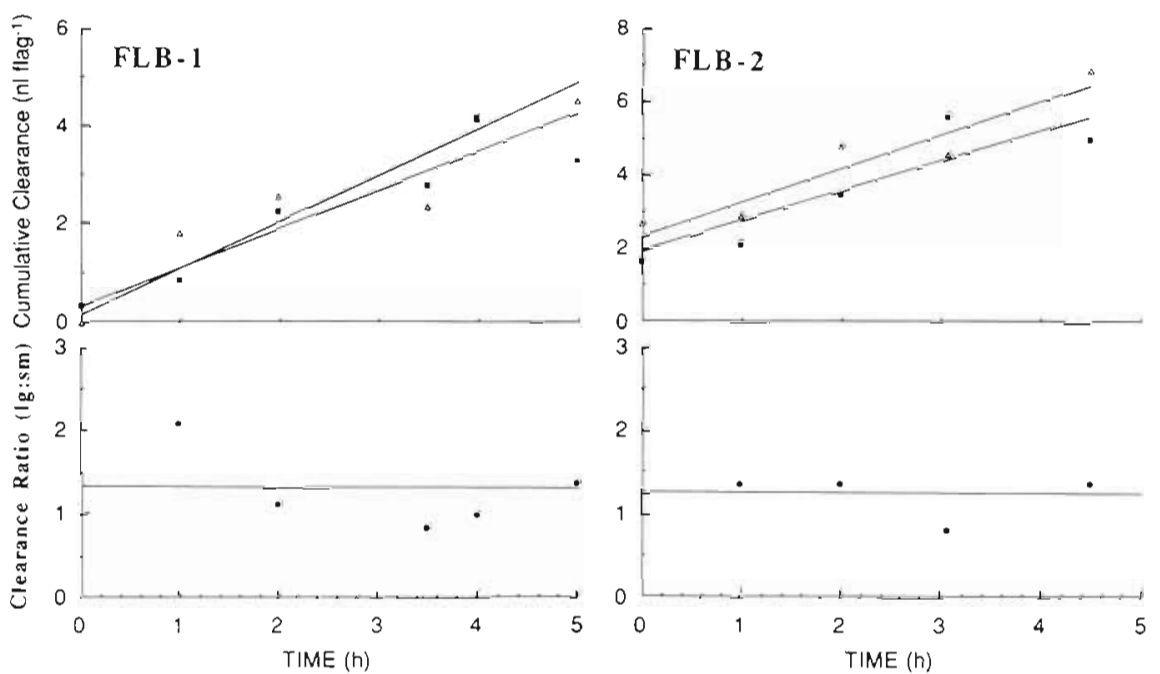

FB model, 4.8 for the GEO model, and 10.9 for the CUBIC model relationship. Similarly, for the size ratio of prey in FLB experiments $\left(R_{1 \mathrm{~g}}=0.51 \mu \mathrm{m} ; R_{\mathrm{sm}}=\right.$ $0.34 \mu \mathrm{m} ; R_{\mathrm{lg}} / R_{\mathrm{sm}}=1.45$ ) clearance rate ratios of $1.4,2.0$, 3.0 are expected for the 3 models, respectively. Table 2 compares these predicted clearance rate ratios with the present experimental results computed in 2 ways - the ratios of the slopes of cumulative volume clearance as determined separately for large and small prey (i.e. the clearance rate ratio) and the mean ratio of large and small prey ingested at individual sampling times (i.e. ratio of cumulative clearance as plotted in lower sections of Figs. 1 to 3 ). While these 2 computational approaches do not yield identical results, they both generally indicate that observed grazing ratios on the different sized prey fall closest to the low extreme of the 3 model predictions (i.e. the predictions of the ForceBalance model)

Two-sided $p$-values obtained from the hypothesis tests of the FB, GEO and CUBIC size-dependency predictions are presented for all experiments in Table 3. For $p<0.05$ there is a statistically significant difference between measured and hypothesized values. For $0.05 \leq \mathrm{p} \leq 0.1$, there is a 'trend towards' a statistically significant difference and for $p>0.1$, there is no statistical difference between measured and predicted ratios (Rosner 1982). According to these definitions, the predictions of Gonzalez et al. (1990) can be rejected in 6 of 7 experiments $(p \leq 0.05)$. In the one experiment where no statistically significant difference was found 
Table 2. Clearance rate estimates (nl flag. ${ }^{-1} \mathrm{~h}^{-1}$ ), with associated standard errors and regression parameters for size-selection feeding experiments. Clearance rate ratios are derived from the quotient of estimated clearance rates on large and small prey computed from regression analysis over the linear portion of the prey ingestion curves. Ingestion ratios and associated $95 \%$ confidence intervals are derived from the mean cumulative volume cleared ratios of large and small prey at each time point. Also presented are the clearance rate ratios (PCCR) predicted by the FB, GEO and CUBIC models (see text for explanation)

\begin{tabular}{|c|c|c|c|c|c|}
\hline \multirow[t]{2}{*}{ Experiment } & \multicolumn{2}{|c|}{ Clearance rate (standard error, $r^{2}$ ) } & \multirow{2}{*}{$\begin{array}{l}\text { Clearance } \\
\text { rate ratio }\end{array}$} & \multirow{2}{*}{$\begin{array}{l}\text { Ingestion ratios } \\
\text { mean }(95 \% \text { CI) }\end{array}$} & \multirow{2}{*}{$\begin{array}{c}\text { PCRR } \\
(\mathrm{FB}, \mathrm{GEO}, \mathrm{CUBIC})\end{array}$} \\
\hline & Large prey & Small prey & & & \\
\hline FMS-1 & $5.7(0.2,0.99)$ & $1.4 \quad(0.26,0.88)$ & 4.1 & $2.6(1.6-3.5)$ & $(1.9,4.8,10.9)$ \\
\hline FMS-2 & $0.21(0.026,0.96)$ & $0.071(0.005,0.98)$ & 2.9 & $1.9(1.5-2.4)$ & $(2.1,4.8,10.9)$ \\
\hline FMS-3 & $2.2(0.93,0.66)$ & $1.7 \quad(0.81,0.60)$ & 1.3 & $1.4(0.95-1.8)$ & $(2.1,4.8,10.9)$ \\
\hline FMS- $4 \mathrm{a}$ & $2.6(0.55,0.88)$ & $2.1 \quad(0.43,0.89)$ & 1.2 & $1.6(0.70-2.6)$ & $(2.1,4.8,10.9)$ \\
\hline FMS- $4 b$ & $0.88(0.20,0.87)$ & $0.71(0.26,0.71)$ & 1.2 & $1.6(1.3-2.0)$ & $(1.9,4.8,10.9)$ \\
\hline FLB-1 & $0.77(0.15,0.87)$ & $0.72(0.13,0.88)$ & 1.1 & $1.3(0.67-1.9)$ & $(1.4,2.0,3.0)$ \\
\hline FLB-2 & $0.89(0.20,0.87)$ & $0.74(0.049,0.99)$ & 1.2 & $1.2(0.80-1.7)$ & $(1.4,2.0,3.0)$ \\
\hline
\end{tabular}

(FMS-3), the p-value for the test of the FB prediction was substantially higher than that of either the CUBIC or GEO predictions. The predictions of the GEO model can be confidently rejected in only 2 of 7 experiments ( $p \leq 0.05$ ) but marginally rejected in 2 others (FMS $-4 a$, $p=0.10 ;$ FLB-1, $p=0.06$ ). In all experiments, however, the predictions of the GEO model were well out of the $95 \%$ confidence intervals for observed mean ingestion ratios (Table 2 ). The predictions of the FB model could be rejected in only one experiment (FMS-1) according to the test of regression slope ratios, and in all but one case (FMS-3) the predictions of the FB model were contained within the $95 \%$ confidence intervals for observed ingestion ratios (Table 2). In retrospect, the use of Paraphysomonas vestita as the flagellate predator in experiment FMS-1 may not have been prudent since its numerous spiny projections (e.g. Fenchel 1982a) violate the smooth surface assumptions of the

Table 3. Hypothesis test, using current experimental results, of the relationship between clearance rate and prey size derived from the Force-Balance model (FB), the Geometric model (GEO) and the empirical relation of Gonzalez et al. (1990) (CUBIC). p-values are determined for each relationship by assuming that clearance rate is proportional, roughly (see text for details), to the first, second and third powers of prey radius (Eq. 1) for, respectively, the 3 models. The Student's t-statistic given by Eq. (2) was used to determine the p-value

\begin{tabular}{|lccc|}
\hline Experiment & FB & $\begin{array}{c}\text {-values } \\
\text { GEO }\end{array}$ & CUBIC \\
\hline FMS-1 & $<0.001$ & 0.42 & 0.01 \\
FMS-2 & 0.06 & 0.01 & $<0.001$ \\
FMS-3 & 0.51 & 0.19 & 0.12 \\
FMS-3a & 0.20 & 0.01 & 0.006 \\
FMS-4b & 0.34 & 010 & 0.05 \\
FLB-1 & 0.35 & 0.06 & 0.01 \\
FLB-2 & 0.50 & 0.40 & 0.002 \\
\hline
\end{tabular}

FB and GEO models and because its ability to discriminate among prey may involve active behaviors (e.g. Goldman \& Dennett 1990, Landry et al. 1991).

\section{DISCUSSION}

The experimental results presented in this paper provide the first test of 3 possible relationships between clearance rate of direct-interception feeding marine flagellates and prey size (Fenchel 1982a, Gonzalez et al. 1990, Monger \& Landry 1990). Although grazing estimates based on microscopical enumeration of fluorescently labelled prey added at tracer densities are inherently 'noisy' and imprecise, the 3 size relationships differ sufficiently to be distinguishable statistically. Our results generally support the predictions of the Force-Balance model over the other 2 size relationships. That is, clearance rates of flagellates tend to vary in proportion to prey radius rather than prey surface area or volume.

Monger \& Landry (1990) showed that the Geometric model of prey capture by flagellates (Fenchel 1982a, 1984) was a special case of the more general ForceBalance model when hydrodynamic boundary effects and surface forces were neglected. While the present results do not necessarily validate the detailed formulation of the Force-Balance model, they do provide a stronger measure of confidence in its ability to yield reasonable predictions. Although lacking a strong physical basis, the intuitive formulations of Fenchel (1986a, b. 1987) also suggest that the clearance rate of flagellates might be directly proportional to prey radius which, in turn, provide additional support for the present experimental results and the predictions of the Force-Balance model. Fenchel's proposed linear dependency of clearance rate and prey radius has previously been invoked to explain the results in other 
studies of flagellate prey selection (e.g. McManus \& Fuhrman 1986, Goldman \& Dennett 1990). Admittedly, none of the evidence yet presented offers complete verification of the predictability of the Force-Balance model; the accuracy and precision of experimental techniques to measure flagellate grazing rates will have to be improved before such substantiating evidence can be provided.

Our experimental results are in direct conflict with the size-relationship inferred from the regression of Gonzalez et al. (1990, Fig. 3). As pointed out in the 'Introduction', the authors never intended to critically compare other possible relationships between clearance rate and prey size, but the high correlation coefficient $(r=0.96)$ of the linear regression between flagellate clearance rate and prey volume (Gonzalez et al. 1990, Fig. 3) could be interpreted as strong evidence for a cubic dependency of clearance rate on prey radius. However, we regressed the same clearance rate data against the corresponding equivalent prey radius and found a nearly identical correlation coefficient $(\mathrm{r}=$ 0.93). Furthermore, we calculated the p-values for all possible paired permutations of the experiments plotted in their Fig. 3 (Gonzalez et al. 1990, Table 2; assuming 4 time points per regression) and obtained average p-values of $0.39,0.28$ and 0.22 , respectively, for clearance rate proportional to the cube, the square and the 0.9 power of prey radius, indicating that while there is a slightly better correspondence to the cubic relationship, neither relationship can be rejected with certainty. The data of Gonzalez et al. are inadequate for revealing the true dependency of clearance rate on prey size because they deal with a very narrow range of prey radii (0.19 to $0.27 \mu \mathrm{m}$ equivalent spherical radius). Over such a range, the predicted clearance rate ratio on large and small prey is only about 2 -fold higher for clearance rate proportional to prey volume than for clearance rate proportional to prey diameter. This small difference cannot be resolved statistically with present direct-counting methods. Gonzalez et al. also presented results of a set of 4 grazing experiments in which a much larger difference in prey size was utilized (natural bacterioplankton FLB: $0.27 \mu \mathrm{m}$ equivalent spherical radius; FLB from 2 strains of cultured enteric bacteria: $0.54 \mu \mathrm{m}$ equivalent spherical radius) (Gonzalez et al. 1990, Table 1). A linear regression analysis analogous to that performed for the experiments presented in Gonzalez et al. (1990, Fig. 3) yields correlation coefficients of 0.39 and 0.40 for clearance rate against prey volume and prey radius respectively. We calculated p-values for these 4 experiments, taking the 3 possible permutations of the experiments run on $9 / 16$, and obtained average p-values of $0.26,0.45$ and 0.33 for clearance rate proportional to the cube, the square and the 0.9 power of prey radius, respectively.
These $\mathrm{p}$-values indicate that these experimental results fit the GEO model predictions better than the other 2 models, however none of the models can be rejected confidently. In this case the prey size differences are probably great enough, but the scatter in the data (i.e. very low regression coefficient) leads to the large p-values for all 3 relationships. Since the data of Gonzalez et al. (1990) do not imply rejection of any of the 3 size-relationships being discussed, they are not in conflict with our present results, which suggest that clearance rate increases roughly with prey radius.

Size-selective grazing has been invoked to explain many aspects of the ecology of bacteria in the oceans. Ammerman et al. (1984) proposed that preferential grazing of larger bacteria was a possible mechanism for maintaining the relatively small size of bacteria in pelagic environments. They also pointed out that if flagellates preferentially graze larger bacteria, cells in the pre-division stage should experience higher than average grazing rates. Andersson et al. (1986) further suggested that grazing influences seasonal shifts in the size-distribution of bacterioplankton. Moreover, Krambeck (1988) first proposed, and Gonzalez et al. (1990) restated, that selective cropping of larger, faster-growing bacteria will shift the natural bacterial population towards smaller, slower-growing forms and thereby indirectly influence the rate of bacterial production.

The effectiveness of size as a refuge from predation depends on how rapidly clearance rate falls off with bacterial size. For example, if dividing cells are approximately double the volume of recently divided cells, the size-dependency implied by Gonzalez et al. (1990, Fig. 3) would mean that pre-division cells suffer double the rate of grazing mortality relative to post-division cells. In contrast, the present results suggest a grazing mortality enhancement on dividing cells of only $20 \%$. This may be ecologically significant at the population level, but difficult or impossible to measure experimentally with present techniques. Differences among the predicted grazing size relationships are greatly magnified over the natural size range of bacteria. For instance, the clearance rate on 1.0 um diameter bacterial cells will be roughly 4,25 and 125 times greater than on $0.2 \mu \mathrm{m}$ diameter cells according to the predictions of the $\mathrm{FB}$, GEO and CUBIC models, respectively. If grazing mortality were proportional to bacterial cell volume, one could readily imagine a significant dormant population of small cells with turnover time on the order of several months to a year. If mortality rates were more nearly proportional to cell diameter, however, the existence of a significant long-term dormant condition would be questionable. To replace losses due to grazing, the smallest bacterial forms must either have a significant specific growth rate or experience a significant recruitment from larger forms (e.g. direct shrinkage of the 
larger forms or enhanced division rate relative to biomass accumulation rate). In either case the smallest bacteria would represent an important and dynamic component of the marine food web.

The extent to which we are able to use present models to predict feeding selection of flagellates depends on the relative contributions of active and passive feeding mechanisms. Active mechanisms are those that involve behavioral responses of flagellates to physical or chemical cues, which may include long-range chemotaxis along chemical gradients of dissolved material or recognition of prey after contact based on specific surface receptor compatibility (e.g. lectin-sugar-like interactions). The Force-Balance model makes no allowances for active prey recognition or capture mechanisms and ignores the possibility of rejection of prey after contact. As a result, the model's utility for predicting selection among prey with different surface or chemical characteristics (i.e. intraspecific differences) is unknown. To date, a growing literature suggests that size is a dominant component of food selection among flagellates. Dubowsky (1974) showed that the freshwater chrysomonad Ochromonas malhamensis exhibited no selection between autoclaved bacteria (Aerobacter aerogenes) and polystyrene latex microspheres of similar shape, size and density. McManus \& Fuhrman (1986) observed an apparent preference by a cultured chrysomonad for Synechococcus over fluorescent paint particles, which they noted could be explained by size alone assuming a linear relationship between clearance rate and prey radius. Gonzalez et al. (1990) found that natural estuarine populations of flagellates grazed 2 different bacterial marine isolates of approximately the same size, but different shape, at about the same rate, and did not appear to distinguish between a gram-positive and a gram-negative enteric bacterial strain of the same general size and shape. These authors combined this information with the strong correlation observed between cell size and clearance rate to conclude that the flagellate population selected predominantly on the basis of prey size. Results of the present experiments (FLB-1. FLB-2) also support the tact that flagellates are selecting predominantly on the basis of size, and because there is good agreement between grazing on FLB and natural bacterioplankton assemblages (Bloem et al. 1988, Sherr et al. 1989) it is probable that size is important in natural systems. It would be well to keep in mind, however, that in some situations the heat-killing process used to produce FLB may eliminate important chemical differences between corresponding live bacterial strains and thereby enhance the importance of prey size as selection parameter (see Landry et al. 1991).

Active selection mechanisms have been advanced to explain lower than expected clearance rates on fluorescent microspheres or paint particles (Pace \& Bailiff 1987, Sherr et al. 1987). While active behaviors cannot be confirmed from these experiments because of a lack of controls (i.e. no alternative prey offered simultaneously), they do serve as a warning of potential problems in assuming prey size is the only relevant parameter influencing flagellate feeding rates and selectivities. Chemosensory behavior has been shown to exist among some flagellates exposed to gradients of dissolved compounds or bacterial numbers (e.g. Sibbald et al. 1987, Bennett et al. 1988, Mitchell et al. 1988). However, it is not certain whether these chemosensory behaviors are significant to grazing in the natural environment because they depend on the magnitude and persistence of gradients and this is not well known. Finally, the Force-Balance model assumes that prey and flagellates are randomly distributed in the medium, and that grazer ingestion experiments that use inert prey (i.e. FLB and fluorescent microspheres) as tracers measure grazing on randomly distributed particles. Azam et al. (1990) have speculated that a close association may exist between particulate organic matter (including live phytoplankters) and heterotrophic bacteria and bacterivorous protists in which the microbes cluster in high density around nutrient-rich microzones of the larger particles. To this end, it may be inappropriate to apply results either from current models, which assume random distribution, or from grazing experiments that use inert prey as tracers to the natural environment.

The experiments presented in this paper provide preliminary support for the predictions of a prey capture model based entirely on the interactions of hydrodynamics and surface forces when organisms the size of flagellates and bacteria encounter one another in high ionic strength media. The usefulness of this model will depend on the relative importance of passive and active selection. In the present experiments, we attempted to isolate prey size from other variables (i.e. intraspecific differences) to demonstrate the effect of prey size alone on flagellate grazing rate. Thus, our experiments cannot be used to determine the relative importance of passive and active selection. Present literature leaves open the possibility that prey size may be of dominant importance to grazing, but artifacts inherent in current experimental techniques make extrapolations to the natural environment problematic. As theory is further refined and as our data base of observations grow, it should be possible to use these models to factor out the contributions of passive capture mechanisms to prey selection. This should then reveal the extent of the more complex problem of active prey selection among marine flagellates in natural enviromments. 
Acknowledgements. We gratefully acknowledge the helpful suggestions of $\mathrm{J}$. A. Baross and P. Welander in the initial stages of this work. We also thank $T$ Fenchel, E. Sherr, B. Sherr, J. Gonzalez and an anonymous reviewer for helpful comments on the original manuscript. This research was supported by National Science Foundation Grants: OCN-8841886 and $O C N-8800089$.

\section{LITERATURE CITED}

Ammerman, J. W., Fuhrman, J. A., Hagstrom, A., Azam, F. (1984). Bacterioplankton growth in seawater: I. Growth kinetics and cellular characteristics in seawater cultures. Mar Ecol. Prog. Ser. 18: 31-39

Andersson, A., Larsson, U., Hagstrom, §. (1986). Size-selective grazing by a microflagellate on pelagic bacteria. Mar. Ecol. Prog. Ser. 33: 51-57

Azam, F., Fenchel, T., Field, J. G., Gray, J. S., Meyer-Reil, L. A., Thingstad, F. (1983). The ecological role of watercolumn microbes in the sea. Mar Ecol. Prog. Ser. 10: $257-263$

Azam, F., Cho, B. C., Smith, D. C., Simon, M. (1990). Bacterial cycling of matter in the pelagic zone of aquatic ecosystems. In: Tilzer, M., Serruya, C. (eds.) Large lakes: ecological structure and function. Springer-Verlag, Berlin, p. $477-488$

Bennett, S. J., Sanders, R. W., Porter, K. G. (1988). Chemosensory responses of heterotrophic and mixotrophic flagellates to potential food sources. Bull. mar Sci. 43: 764-771

Bloem, J., Starink, M., Bar-Gilissen, M. B., Cappenberg, T E. (1988). Protozoan grazing, bacterial activity, and mineralization in two-stage continuous cultures. Appl environ. Microbiol. 54: 3113-3121

Campbell, L., Carpenter, E. J. (1986). Estimating the grazing pressure of heterotrophic nanoplankton on Synechococcus spp. using the sea water dilution and selective inhibitor techniques. Mar. Ecol. Prog. Ser. 33: 121-129

Dubowsky, N. (1974). Selectivity of ingestion and digestion in the chrysomonad flagellate Ochromonas malhamensis. J. Protozool. 21: 295-298

Fenchel, T (1982a). Ecology of heterotrophic microflagellates. I. Some important forms and their functional morphology. Mar. Ecol. Prog. Ser. 8: 211-223

Fenchel, T (1982b). Ecology of heterotrophic microflagellates. IV Quantitative occurrence and importance as consumers of bacteria. Mar Ecol. Prog. Ser 9:35-42

Fenchel, T. (1984). Suspended marine bacteria as a food source. In: M. J. Fasham (ed.) Flow of material and energy in marine ecosystems. Plenum Press, New York, p. $301-315$

Fenchel, $\Upsilon$ (1986a). The ecology of heterotrophic microflagellates. Adv. microb. Ecol. 9: 57-97

Fenchel, T (1986b). Protozoan filter feeding. Prog. Protistol. 1 $65-113$

Fenchel, T (1987). Ecology of protozoa: the biology of freeliving phagotrophic protists. Springer-Verlag, New York

Fenchel, T. (1988). Marine plankton food chains. Ann. Rev. Ecol. Syst. 19: 1938

Goldman, J. C., Dennett, M. R. (1990). Dynamics of prey selection by an omnivorous flagellate. Mar. Ecol. Prog. Ser. 59: 183-194

Gonzalez, J. M., Sherr, E. B., Sherr, B. F. (1990). Size-selective grazing on bacteria by natural assemblages of estuarine flagellates and ciliates. Appl. environ. Microbiol. 56 583-589

Iturriaga, R., Mitchel, B. G. (1986). Chroococcoid cyanobac- teria: a significant component in the food web dynamics of the open ocean. Mar Ecol. Prog. Ser 28: 291-297

Kendall, M. G., Stuart, A. (1961). The advanced theory of statistics, Vol. 2. Hafner Publ. Co., New York

Krambeck, C. (1988). Control of bacterioplankton structure by grazing and nutrient supply during the decline of an algal bloom. Verh. int. Verein. Limnol. 23: 496-502

Landry, M. R., Lehner-Fournier, J. M., Sundstrom, J. A., Fagerness, V L., Selph, K. E. (1991). Discrimination between living and heat-killed prey by a marine zooflagellate Paraphysomonas vestita (Stokes). J. exp. mar. Biol. Ecol 146: 139-151

Linley, E. A. S., Newell, R. C., Lucas, M. I. (1983). Quantitative relationship between phytoplankton, bacteria and heterotrophic microflagellates in shelf waters. Mar. Ecol. Prog. Ser. 12: 77-89

Maaløe, O., Kjeldgaard, N. O. (1966). Control of macromolecular synthesis: a study of DNA, RNA, and protein synthesis in bacteria. W. A. Benjamin Inc., New York

McManus, G. B., Fuhrman, J. A. (1986). Bacterivory in seawater studied with the use of inert fluorescent particles. Limnol. Oceanogr 31: 420-426

McManus, G. B., Fuhrman, J. A. (1988). Clearance of bacteriasized particles by natural populations of nanoplankton in the Chesapeake Bay outflow plume. Mar Ecol. Prog. Ser. 42: $199-206$

Mitchell, G. C., Baker, J. H., Sleigh, M. A. (1988). Feeding of a freshwater flagellate, Bodo sultans, on diverse bacteria. J. Protozool. 35: 219-222

Monger, B. C., Landry, M. R. (1990). Direct-interception feeding by marine zooflagellates: the importance of surface and hydrodynamic forces. Mar Ecol. Prog. Ser. 65: 123-140

Nygaard, K., Borsheim, K. Y., Thingstad, T. F. (1988). Grazing rates on bacteria by marine heterotrophic microflagellates compared to uptake rates of bacterial-sized monodispersed fluorescent latex beads. Mar. Ecol. Prog. Ser 44 : $159-165$

Pace, M. L., Bailiff, M. D. (1987). Evaluation of a fluorescent microsphere technique for measuring grazing rates of phagotrophic microorganisms. Mar Ecol. Prog. Ser 40: 185-193

Platt, T., Denman, K. (1977). Organization in the pelagic ecosystem. Helgoländer wiss. Meeresunters. 30: 575-581

Rassoulzadegan, F., Laval-Peuto, M., Sheldon, R. W (1988). Partitioning of the food ratio of marine ciliates between pico- and nanoplankton. Hydrobiol. 159: 75-88

Rohlf, F. J., Sokal, R. R. (1981). Statistical tables, 2nd edn. W. H. Freeman Co., New York

Rosner, B. (1982). Fundamentals of biostatistics. Duxbury Press, Boston

Sheldon, R. W., Sutcliffe Jr, W. H., Paranjap, M. A. (1977). Structure of pelagic food chain and relationship between plankton and fish production. J. Fish. Res. Bd Can. 34: $2344-2353$

Sherr, B. F., Sherr, E. B., Berman, T (1983). Grazing, growth, and ammonium excretion rates of a heterotrophic microflagellate fed with four species of bacteria. Appl. environ. Microbiol. 45: 1196-1201

Sherr, B. F., Sherr, E. B., Fallon, R. D. (1987). Use of monodispersed, fluorescently labeled bacteria to estimate in situ protozoan bacterivory. Appl. environ. Microbiol. 53: 958-965

Sherr, B. F., Sherr, E. B., Rassoulzadegan, F. (1988). Rates of digestion of bacteria by marine phagotrophic protozoa: temperature dependence. Appl. environ. Microbiol. 54: 1091-1095

Sherr, B. F., Sherr, E. B., Pedros-Alio, C. (1989). Simultaneous 
measurement of bacterioplankton production and protozoan bacterivory in estuarine water. Mar Ecol. Prog. Ser. 54: 209-219

Sibbald, M. J., Albright, L. J., Sibbald, P. R. (1987). Chemosensory responses of a heterotrophic microflagellate to bacteria and several nitrogen compounds. Mar Ecol. Prog. Ser. 36: 201-204

Sieracki, M. E., Haas, L. W., Caron, D. A., Lessard, E. J. (1987). Effect of fixation on particle retention by microflagellates: underestimation of grazing rates. Mar. Ecol. Prog. Ser 38: $251-258$

This article was submitted to the editor
Sokal, R. R., Rohlf, F. J. (1981). Biometry: the principles and practice of statistics in biological research, 2nd edn. $W H$. Freeman and Co., New York

Spielman, L. A. (1977). Particle capture from low-speed laminar flows. Ann. Rev. Fluid. Mech. 9: 297-313

Stevenson, H. L. (1978). A case for bacterial dormancy in aquatic systems. Microb. Ecol. 4: 127-133

Wright, R. T (1984). Dynamics of pools of dissolved organic carbon. In: Hobbie, J. E., Williams, P. J. leB. (eds.) Heterotrophic activity in the sea. Plenum Press, New York, p. $121-154$

Manuscript first received: November 9, 1990

Revised version accepted: May 23, 1991 